https://doi.org/10.22364/htqe.2019.12

\title{
A GAME FOR SELF-DISCOVERY IN A CAREER-CHOICE DISCOURSE FOR ADOLESCENTS
}

\author{
Mārtiṇš Geida \\ University of Latvia, Latvia
}

\begin{abstract}
The research examines the use of the didactic game for self-discovery in a career choice discourse for adolescents, to develop and practically approbate the didactic game to promote adolescent self-discovery. The theoretical aspects of the essence of self-discovery, the psychophysiological peculiarities of self-discovery during adolescence, the elements of self-learning during adolescence from the point of view of career guidance were considered. The role of the game in human life has been studied, as well as the role of the didactic game in supporting the learning process and career guidance, the importance of the game for selfdiscovery. The empirical research describes the pedagogical experiment conducted with the help of the didactic game "Pass On", which was developed by the author, used with students of Years 7 to 9 in examining the basic career questions: Want, Can, Need, and their opposites Do Not Want, Can Not, Do Not Need. Methods of data collection: a survey, questionnaires, interviews. The obtained results were quantitatively and qualitatively processed. The main conclusions of the study: didactic play is a valuable learning technique for self-knowledge, which provides an essential understanding of one's skills and abilities, develops logical and critical thinking, promotes awareness of earlier career choice research and its need during adolescence. Improves the microclimate in the class, promotes socialisation, collaboration and communication skills in the class.
\end{abstract}

Keywords: Self-discovery, adolescence, didactic game, career choice, career management skills.

\section{Introduction}

Pedagogical experience has shown that teachers at school really "chase after their students" to ensure that they complete all the tasks according to the curriculum. Up until the end of the $9^{\text {th }}$ grade, this tendency is very pronounced as primary education in Latvia is compulsory (Constitution of 
the Republic of Latvia, Article 112). Moreover, it is crucial for teachers, not students, that the national guidelines are met. Therefore, contrary to the mandatory conditions which are not particularly relevant for the students themselves, it is vital to ensure that the unity of freedom, autonomy and responsibility is implemented through new ways and techniques. For students, this would contribute to the personal interest in taking responsibility for the development of their life skills and career management skills. The society needs full-fledged members, which is also in line with the objectives set by the Education Law:

1. To acquire knowledge, skills and experience in attitudes, in order to participate in the life of the State and society;

2. For moral, aesthetic, intellectual and physical development, by promoting the development of a knowledgeable, skilful and socialised individual (Education Law, 1998).

Not only the development of a skilled and educated personality but the development of a character that is personally interested, responsible, independent and free. This is possible through ways, methods, techniques and means that are different from those that have prevailed so far. Therefore, career education, starting with the preschool stage, could be the binding element that makes formal education interesting, which promotes the transformation of formal education with the help of elements that link the current needs of children, students, adolescents and young people with the values, skills and competencies that will be needed throughout life. This means that there is a need for a personal interest in participation in the Lifelong Learning Programme, starting from childhood as envisaged in the 2008 Council of Europe Resolution on better integration of lifelong career guidance into lifelong learning strategies (ELGPN).

The central principle of humanism - human value - is still being updated in today's theorists' ideas (Dauber, 2009; Barrett, 2010; Huitt, 2011).

In the economy, the most valuable resources are human resources; its fundamental problems include unlimited desires and limited resources. Their resolution and economic development depend on how well each individual can apply their internal resources: competences, abilities, talents, throughout their lives through a career prism that includes five areas: work, family, recreation, spiritual development and citizenship.

Career guidance involves the development of self-centred career management skills consisting of self-discovery, career prospecting and creation skills, career planning skills, decision-making skills and the ability to cope with uncertainty (Ireland's National Career Guidance, 2019).

The preparation of a person for a career is primarily carried out using an educational system which is responsible for: ensuring the continuity of cognitive processes, organising teaching and learning, preparing people for 
life in interaction with the society. Career is already a lifestyle in interaction with society, where the most critical aspect is the discovery of human abilities, talents, resources - self-discovery. Self-discovery intertwines with the exploration of the processes in society in accordance with existential questions: want - do not want, can - cannot, need - do not need, which help to assess themselves, their desires and needs in the context of the processes taking place in society.

The novelty, scientific and practical contribution of the research is theoretically justified by the need for self-discovery of Year 7 students; the methodology of didactic games for self-cognition of Year 7 students has been developed, approbated and evaluated; suggestions and recommendations for using the didactic game for self-discovery in the career guidance discourse for teenagers, which is available to school leaders, class teachers, subject teachers, career counsellors, educators - career consultants, students, etc.

\section{State of Art}

When looking at the concepts used in the research, it should be emphasised that: two parts of self-discovery should be examined:

- self (I; my, me, myself, mine);

- cognition (cognitive process, knowledge acquisition, research, familiarisation, identification, evaluation).

There are several variations: self-discovery, self-study, selffamiliarisation, self-evaluation, self-determination (Geida, 2017). As a result of self-study, an individual acquires a perception of themselves.

The self-concept is viewed as a self-image, the "I" image, the "I" concept - I AM, which has been formed since early childhood. However, a person is a social being and their existence, including career development and management skills, must be viewed closely in relation to the processes in society, existing social and cultural beliefs, values, that are continually changing.

The cognition (discovery or inquisition) is the reflection (conceiving and mastering) of the phenomena actually observed, their essence and regularity in human consciousness. This process involves the ability to go deeper, understand concepts and ideas (Belickis, Bluma, 2000). The result of the cognitive process is the acquisition of knowledge, both theoretical and practical (Belickis, Bluma, 2000). Knowledge is the result of cognition processes obtained in the form of theoretical and practical lessons learned. "I" find out, the result is "I" know, when the process stops. An individual examines the state of their internal resources - their level of development. Theoretical knowledge is data and their interrelations. Practical knowledge is experience, abilities, skills and competencies. Part of the experience 
gained may already be expressed in life as a conditioned reflex, an action that happens automatically. A person has developed the abilities for so long that they have become skills that no longer require deliberate action everything happens automatically. The state of knowledge, "I know", can be compared to the potential energy in physics, which is a stable, sustainable state. A certain conviction, a concept of the current role, a position, emerges when transferring it to human consciousness. The cognitive process, in turn, can be compared to kinesthetic energy that, which is always in motion and can be observed in dynamic interaction with the environment.

Making the most of the opportunities and peculiarities of development available in the respective age groups could achieve significant results in managing one's life based on one's self-knowledge.

The adolescence is associated with the most considerable changes in the life of a person when the transition from child consciousness to adult consciousness occurs, with the new "I" in the centre. It affects not only the physiological changes but also the relationships developed with peers and adults, which in turn influence the level of development, intelligence, skills of the cognitive process. A teenager is a person in the age between a child and a young person (about 11/12-15/16 years old) in the transition from childhood to youth. This age is associated with significant physiological changes, a desire for autonomy, independence. Self-awareness and selfassessment are evolving. Tendencies of self-education appear (Belickis, Blūma, 2000).

Socialisation and the expression of "I" are identified as the most important factors from the perspective of pedagogy and psychology scientists for teenagers - the awareness of their own "I", focusing on getting to know themselves through interaction with society. The main difficulties in adolescence are associated with insufficient self-awareness and difficulties in the process of decision-making (Greenhaus, Callanan, 1994).

The characteristics identified by career-choice researchers in relation to this age phase are the following: In the relationship between the roles and stages of life, there is an ongoing exploration, a search for one's new "I", especially in the context of socialisation, as well as examination of interests (Super, 1980; Latsone, Mackeviča, 2008.). Meanwhile, the research on career development conducted by Super in 1963 among 14-year-olds contributed to the emergence of a new concept of career maturity, in which six areas were distinguished, including understanding of one's attributes self-image formation and career orientation - an individual's attitude to possible career choices (Latsone, Mackeviča, 2008). His career development model and research supported the need for career education within the framework of career guidance and the importance of promoting career 
maturity and decision-making. Super also notes that the career decisions relate to self-image and role games contribute to the development of professional self-image; this is reinforced by practical trials. According to the periodisation of professional advancement of personality established by Klimov, the 12-17-year period was intended for preparation for an informed choice of profession (Климов, 1996). The Career Development Guidance Handbook states that teens are experiencing interest development and capacity development. At age 13-14, young people are starting to have an awareness of their capacity development. Preparation for career planning, career research, decision-making, the study of employment information and career orientation take place during adolescence (Latsone, Mackeviča, 2008).

Between the ages of 14 and 25, there is still a need to prove the current professional choice, to start working in the selected field, there is a desire to explore new opportunities and develop self-perception (Gibson, Mitchell, 2006).

According to the peculiarities of the new psychological and physical phenomena of the age group, adolescents must stay active, interested in various activities. One of the best ways to help a child build a positive selfimage and avoid trouble during the teenage years is to help them develop interests and talents (Lickona, 1983).

It is during the adolescence that fundamentals are put in place for finding one's place in the adult world unless the family does it during childhood. Up to the age of 14 , hobbies or activities that people are interested in are a critical aspect to consider. Becoming an adult is a process filled with emotional and social distress that needs to be made as interesting and exciting as possible so that acceptance of change and self-awareness become integrated and are transformed into a stable personality.

The author of the research recommends using teaching organisation techniques that are interesting and exciting for the students to distract them from the difficult changes happening to their bodies and psyches. This could be facilitated by the use of activities involving movement, such as games.

Game: a creative activity associated with unique techniques and regulations with a developmental and entertaining character (Belickis, Blūma, 2000). In philosophy and culturology, the game is considered to be the essence of human existence, a means of examining the surrounding world; the axiological basis of the game and the value of the cultureethnical phenomenon of the game are examined. In pedagogical science, the game is considered as a form of education and learning, as a component of pedagogical culture; the forms and optimisation of modern games are explored. In psychology, the game is viewed as a tool for activating 
psychological processes; it is used for diagnosis, correction and adaptation; social emotions are studied (Михайленко, 2011).

The game makes the perception of life easy, interesting and exciting for all ages. Games help children to accept and understand the difficulties, contradictions and tragedies of life philosophically, teach them not to give up, see the bright and joyful side of life, rise above the "obstacles of life", live with meaning, rejoice, live with a light-minded perception (Шмаков, 1997).

The didactic game is a situationally variable didactic exercise whose content and teaching nature are partially hidden by form and which involves the creative intellectual activity of participants (Belickis, Blūma, 2000). A didactic game differs from a regular game by having a strictly regulated structure, under which the game has educational significance. The didactic game carries out upbringing and knowledge provision, since its main elements - didactic tasks, game tasks, playing the game, game rules, inventory and outcomes - are well structured and combine both teaching methods and the action of the game (Romadina, 2015).

Variations in the concept of the game: play, game-play, game, gamification.

Play - activities for children without special rules. Game-play - a play with specific rules. Game - a natural, free, imaginary activity whose members willingly comply with the rules. Gamification - a combination of two English words game and education; it is used when it comes to using the elements of the game in the learning process. The introduction and development of a system of support, recognition and awards at all ages, which makes it easy and free (easier and freer) to take on what is happening (Geida, 2017).

The experience of the author of the research shows that the role and meaning of the game are still not taken seriously; teachers oppose the use of didactic games in lessons because they feel as if they must become "circus artists, clowns" who need to entertain pupils. A game is perceived as a non-serious, irresponsible, pointless, entertaining, illusory action focused on the inappropriate use of time within the learning process. In the opinion of the author of the research, joining the game with gamification elements could lead to higher interest, since the evaluation system would become more intensive. This can be observed in, for example, computer games, where a certain number of points of experience make it possible to reach the next level, where various awards and benefits can be used in the progress of the game.

Pointing out the essentials - the game is the essence of human existence, a cognitive tool, a way of upbringing and learning that activates mental processes, it can be seen as a universal form of expression of children that 
allows overcoming the differences between languages, nationalities and other cultural aspects.

At the same time, real and imagined/notional behaviour occurs, an action that is purely conceived by the circumstances and conditions in which the playing person is immersed, imagined during the process of the game; however, the emotional experience is real, thereby creating a relationship between the internal and the external world, when everything is both connected and detached at the same time.

Through collecting information on the concepts mentioned above, the author of the research worked on the development of a didactic game for teenagers in the discourse of career choice, setting out the following research tasks:

1. Study scientific, specialised and methodological literature on the selfdiscovery of Year 7 students in lower secondary school:

- Assess career guidance opportunities with different forms, methods, techniques and means of organising the learning process;

- Examine the learning process of students in lower secondary school, analyse the factors that affect them.

2. Justify the need for a didactic game in the development of students' self-discovery.

3. Develop a methodology for didactic games to encourage students' self-discovery.

4. Perform an experiment on the development of self-discovery of Year 7 students.

5. Develop conclusions and suggestions.

The practical contribution of the research is the methodology for the didactic game "Pass On", approbated between September 2013 and April 2017, with the participation of 81 student of Year 7.

The results of approbation were assessed, and proposals were developed for the further use of games in Year 7 lessons and the development of career management skills in the context of self-discovery.

Methods of data collection: a survey, questionnaires, interviews.

\section{The Stages and Description of Empirical Research}

At the beginning of the school year and the research, the students completed two questionnaires: "I was, I am, I will be" and "Free Time". They played the didactic game "Pass On".

The description of the game: throwing dice with six faces in three primary colours: yellow, red, blue. The inscriptions on the faces, three positive choices (I WANT, I CAN, I NEED) and three negative choices (I DO NOT NEED, I CANNOT, I DO NOT WANT). The game begins with a 
demonstration of the leader of the lesson, by throwing the die in the air, catching it, showing that one has to read the face of the dice that is facing the player while holding the dice in their hands most comfortably, for example, I CANNOT. The die is passed on, calling after the next participant by their name. The next participant reads the choice/phrase from the die aloud; the lesson leader writes it down on the board. And so on until all the participants have played. The next task after the game of dice is to justify one's choice in 10 sentences.

The game was played in 2 versions. In the first versions, each student who caught the dice gave answers about a topic of their own choice, such as what is currently relevant to them. The answers were written on the board. In the second version, each student who caught the dice gave answers about the common theme: work, profession, career.

After each game version, the students answered six questions (time limit for each version with answers - 40 minutes). The final stage of the research was filling out the questionnaire "I want, I can, I do not want, I cannot, I do not need".

The comparison of indicators using a Sign test. WANT1, where the data were collected at the beginning of the school year (do I already know what profession I would like to work in in the future?), and WANT2, where the data were collected 2 months before the end of the school year following a variety of activities in lessons of social science and other subjects as well as activities for the development of career management skills in Year 7 using the didactic game "Pass On", it was concluded that p-value $=0.000$, which is $<0.05$, and indicates that in the course of self-discovery, Year 7 students have demonstrated statistically significant differences when comparing the results at the beginning of the school year and in the second half of the school year. In numerical value, during the 7-month research process, 39 students of Year 7 chose a particular profession (at least in the optional section in the professional interest assessment attempt); there was one student had negative results, and the results stayed constant for 41 students.

The value of WANT1 was identified at the beginning of the school year, in the hobby and interest questionnaire under the question/statement "My Possible Future Career". WANT2 students should have presented in the last activity. The questionnaire contained a Wish to be, work as, with an oral explanation - to try a profession, job. Twenty-five students experienced positive changes, one student - negative changes, 55 students - no changes. This indicator also shows that p-value $=0.000$, which is $<0.05$, indicating that Year 7 students have demonstrated statistically significant differences when comparing the results at the beginning of the school year and in the second half of the school year. 
When assessing the students' written responses on the benefits of this task, 12 pupils indicated that they now had a better understanding of their choices. This statement had similar answers, for example, to be more aware of their choices, to contemplate and justify them, to understand what the students want and what they do not want, to make their options carefully before they do or say something, to assess each of the next answers, to understand why they are saying something, to understand what they can or cannot do, want - do not want, and what is needed or not necessary, to think about what is said, to justify choices, to explore themselves better, to look into different issues which were not explicitly thought about until now, to develop the speed of thinking, to contemplate what should be done now in the choice of the profession, to understand what they do not want, need or cannot, to do more to improve, to begin to be more interested in the choice of the future profession. Several pupils indicated that they had been motivated to for the process, as well as motivated to be aware of their drawbacks, in order to avoid unwanted employment or occupation in the future.

The answers provided by students show that the didactic game with dice and the choice of answers, as well as their justification, develops logical and critical thinking; thus, the basis for sustainable, strategic thinking is laid. The didactic game "Pass On" was tested in practice, in author-led lessons for more than 400 students of Years 7 to 9 throughout Latvia. Two versions were played out - a free choice and a combined theme of work, profession and career. Pupils wrote 10-sentence long justifications for their choices and answered six questions. The opinions of the students on the potential benefits of the game in many ways coincided with the answers from the pilot study: one has to really think, to justify the answers, it seemed interesting, and I enjoyed learning the opinions of the classmates, we enjoyed working together. This shows that the didactic game also promotes collaboration between students in the classroom and improves communication. Of course, such a task can be given to students to perform academically, without an element of the game, but then the possibilities to develop socialisation, team-building and self-presentation skills are missing.

\section{Conclusions}

The students like the didactic game "Pass On" for self-discovery, it makes them think about their needs and desires. A game is a powerful, motivating factor for learning. With the help of the game, the activation of the cognitive process is intensified and faster, and more themes are explored in the game than in the daily learning process. 
The game has more precise, more understandable goals for students compared to academic teaching methods. The development of new psychological formations is essential in adolescence, as emphasised by career scientists, educators and psychologists. Until adolescence, the playful perception of the world in which everything has to be approached with lightness, which means - not stopping when facing difficulties, not giving up, coping with the uncertainty; these are promoted through the didactic game "Pass On". The game can be used as a method to link the needs of a person's inner world with the skills and abilities needed for life/ career, by creating a link with what is already known and new concepts in a light, exciting atmosphere; creating a new, growth-enhancing experience.

In the assessment of the students, the objectives of the game enable them to understand their choices, to assess their motivation, to be more aware of the necessity of their choices and to justify them.

The "Pass On" didactic game is suitable for the upper classes of lower secondary school, for self-discovery, personal and professional interest assessment, familiarisation with professions, the discovery of strengths and weaknesses of students.

Through analysis of the results obtained, it can be concluded that the didactic game "Pass On", developed by the author of the research, contributes to the process of self-discovery during adolescence, according to the questions/statements I want - do not want, I can - I cannot, I need - I do not need, which are the basis of all existential choices and processes, and which are particularly relevant to the physiological and intensive psychological processes, creation of new concepts during adolescence.

\section{References}

Barret, J. (2010). Human Rights, Sustainability and Standing: A Humanist Perspective. Retrieved from Open Polytechnic Web site: https://www. openpolytechnic.ac.nz/assets/Marketing/Research/Current-working-papers/ WP409Humanrightssustainabilitystanding.pdf

Beḷickis I., Blūma D., Koḳe T., Markus D., Skujiņa V. (2000). Pedagoğijas terminu skaidrojošā vārdnīca [Glossary of Pedagogical Terms]. Riga: Zvaigzne ABC.

Dauber, H. (2009). Grundlagen Humanistischer Pädagogik. Leben lernen für eine humane Zukunft [Foundations of Humanistic Education: Learning to Live for a Humane Future]. Bad Heilbrunn: Julius Klinkhardt.

Education Law (1998). Available at Legal Acts of the Republic of Latvia: https://likumi. lv/doc.php?id $=50759$

Geida, M. (2017). Didactic Game for the $7^{\text {th }}$ Grade Students Self-Cogniton. Jelgava: Latvia University of Life Sciences and Technologies.

Gibson L. Robert, Mitchell H. Marianne. (2006). Introduction to Career Counseling for the $21^{\text {st }}$ Century. New Jersey: Pearson/Merrill Prentice Hall. 
Greenhouse, W., Callanan, R. (1994). Career Management. Forth Worth: The Dryden Press.

Huitt, W. (2011). Why study educational psychology? Educational Psychology Interactive. Valdosta: Valdosta State University. Available: http://www.edpsycinteractive.org/ topics/intro/whyedpsy.html

Ireland's National Career Guidance (2019). Available Ireland's National Career Guidance Web site: https://careersportal.ie/

Latsone L, Mackeviča D., Miḳelsone I., Oḷehnoviča E., Strods G. (2008). Karjeras attīstības atbalsts [Career Development Support]. Riga: VIAA.

Lickona, T. (1983). Raising Good Children: From Birth Through The Teenage Years. Bantam Books: New York.

Romadina, A. (2015). Didaktiskās spēles pamatskolas skolēnu motivācijas veicināšanai [Didactic Games to Stimulate Primary School Pupil Motivation]. Jelgava: Latvia University of Life Sciences and Technologies.

Super, D. E. (1980). A Life-Span, Life-Space Approach to Career Development. Journal of Vocational Behavior, 16, 282-298.

Svence, G. (1999). Attīstības psiholog̣ija [Developmental Psychology]. Riga: Zvaigzne ABC.

The Constitution of the Republic of Latvia, The Constitutional Assembly (1922). Available at Legal Acts of the Republic of Latvia: https://likumi.lv/doc.php?id $=57980$

Климов, Е. (1996). Psihologija professionalnogo samoopredelenija: uchebnoe posobie [The Psychology of Professional Self-Determination: A Study Guide]. Ростов-на-Дону: Феникс.

Михайленко, Т. (2011). Igrovye tehnologii kak vid pedagogicheskih tehnologij [Game Technologies as a Type of Educational Technology]. Челябинск: Педагогика: традиции и инновации: материалы Междунар. науч. конф. Т. І. Челябинск: Два комсомольца. Available at https://moluch.ru/conf/ped/archive/19/

Шмаков, С. (1997). Igra uchashhihsja kak pedagogicheskij fenomen kultury [The Game of Students as a Pedagogical Phenomenon of Culture]. Москва. 